\title{
The assemblages of corticioid fungi (Basidiomycetes) in broadleaf-spruce forests in Belarusian Moraine Ridge physiographic province
}

\author{
EUGENE YURCHENKO
}

YURCHENKO, E. 2007: The assemblages of corticioid fungi (Basidiomycetes) in broadleaf-spruce forests in Belarusian Moraine Ridge physiographic province. - Karstenia 47: 17-28. Helsinki. ISSN 0453-3402.

Inventories of corticioid fungi (Basidiomycetes) were carried out on four permanent 400 $\mathrm{m}^{2}$ sample plots scattered over Belarusian Moraine Ridge. Selected coenoses belong to boreonemoral vegetation zone and the forests are dominated by spruce, aspen and oak, of Oxalis and Aegopodium types. The number of corticioid fungi in these forests was in average 37 species, which permits to evaluate Querco-Piceetum as the most species-rich forest type. The largest genera were Hyphodontia (5-7 species per plot) and Peniophora (3-4 species, respectively). In general, the more dead wood was produced by a host the higher was the number of fungal species inhabiting it. In this study spruce plays a minor role as a host for corticioid fungi (in boreonemoral forests), harbouring only a few species. Cluster analyses demonstrated that structure of fungal assemblages is dependent on the type of plant association, and in several cases also on geographical distance between the study sites.

Key words: cluster analysis, Corticiaceae s.1., Querco-Piceetum, sample plot

Eugene Yurchenko, Laboratory of Mycology, V.F. Kuprevich Institute of Experimental Botany, Akademichnaya str. 27, BY-220072 Minsk, Belarus

\section{Introduction}

Belarusian Moraine Ridge (BMR) is a natural area formed as a marginal glacier structure and is traditionally distinguished by physiographists (e.g. Dzayments'eu 1975). In general the province is characterized by hilly relief, and includes three physiographic districts: Ashmyany, Minsk and Orsha eminences (Fig. 1 A). The highest areas of Belarus are located in Minsk Eminence. The average annual precipitation in the study area is $650-700 \mathrm{~mm}$, the average temperature in July is $17.5^{\circ} \mathrm{C}$ and in January -6.5 to $-8^{\circ} \mathrm{C}$, respectively (Lohinau \& Hol'berh 2002).

Non-poroid, non-gilled homobasidiomycetes with effused or effused-reflexed basidiomata, are frequently called "Corticiaceae", even if it is an artificial family. Many of them are special- ized to small-sized dead wood - to both still-attached and fallen branches. A big part of species are poorly studied due to their small or very thin basidiomata, growing on under surface of fallen wood.

According to the vegetation map of Adzyarykha et al. (2002) the communities belong to Southern Taiga Broadleaf-Spruce Forests of Oxalis and Aegopodium types, which occur in central and northern zones of the country. The forests are dominated by spruce (Picea abies) intermixed with aspen tree (Populus tremula), birch (Betula pendula), grey alder (Alnus incana), oak (Quercus robur) and maple (Acer platanoides), with Oxalis acetosella and Aegopodium podagraria in field layer. 
The aim of this study was to compare the species compositions of four communities having more or less similar vascular plant compositions and tree stands, and to find out the factors determining fungal assemblages. I also wanted to compare these results with those of Yurchenko (2003b). For the term "community" pro and contra the reader is referred to Zmitrovich et al. (2003).

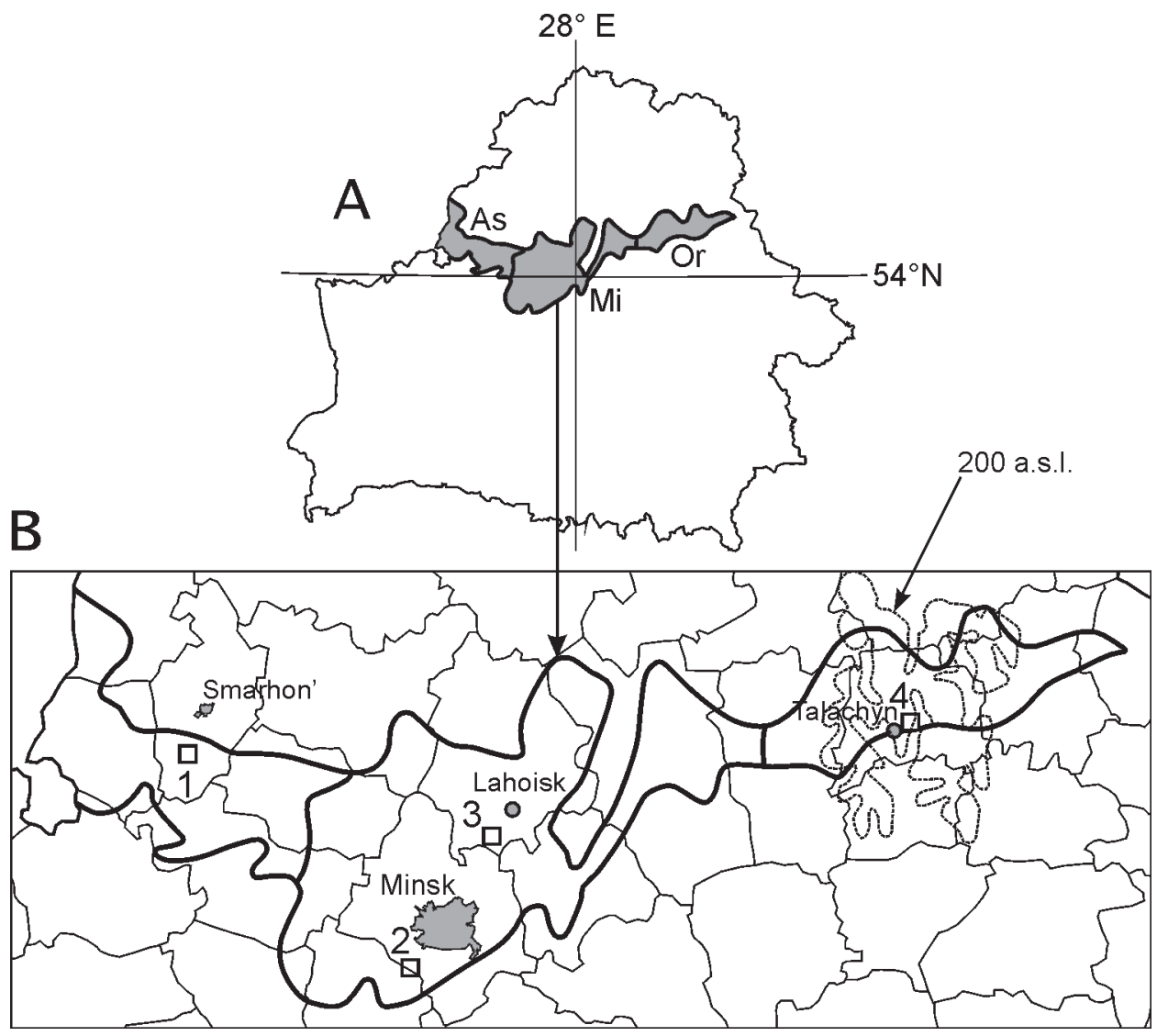

Fig. 1. Belarusian Moraine Ridge Physiographic Province with districts of Ashmayny Eminence - As, Minsk Eminence - Mi, and Orsha Eminence - Or (A), and positions of the four sample plots in the physiographic (thick lines) and administrative (thin lines) districts (B). The approximate relief borders of Orsha Eminence are depicted via the contour line $200 \mathrm{~m}$ above sea level ('200 a.s.l.' on the figure).

\section{Materials and methods}

Field collections were carried out in 2001-2003, and each plot was visited 2-3 times (Table 1). Permanent plots were placed in forests where the flora is as similar as possible with the earlier investigated Querco-Piceetum in Byarezinski Biosphere Reserve (Yurchenko 2003b). The boundaries of the $20 \times 20 \mathrm{~m}$ plots were properly marked (ropes, sketches etc.). The plots were chosen so that the homogeneity of the vegetation within each plot was as high as possible. The plots were in three physiographic districts over the study province. Plots 1 and 3 are close to the highest parts of the eminences (Fig. 1 B). Plot 4 was at the south edge of the physiographic district because the central part of this district in fact lacks broadleaf-spruce communities and are mostly occupied by boreal spruce forests. In the inventory all corticioid fungi were collected from dead wood, but sometimes also from litter close to fallen trunks. Sometimes the substratum was identified microscopically.

The plot abbreviations used in herbarium labels and other documentation are shown in Table 1. The collections are preserved in V.F. Kuprevich Institute of Experimental Botany, Fungal Herbarium (MSK-F). 
The nomenclature of fungi mostly follows CORTBASE vers. 2 (see Parmasto 1997), and the authors are not repeated here. Some nomenclatural exceptions are: Athelia epiphylla complex is according to Hansen and Knudsen (1997) and the concept of Hyphoderma praetermissum follows Hallenberg et al. (1994). Also Schizopora species are treated under Hyphodontia and Sistotrema niveocremeum in Sistotremastrum.

Similarity index (Sørensen's Quotient, Q.S.) was calculated as e.g. in Renvall (1995: 6). The cluster analyses were carried out by STATISTICA 5.0A (StatSoft, Inc., 1995) software. The value 1-Pearson's Correlation Coefficient (1-Pearson r) was used as distance measure on dendrograms; the selected clusterization algorithms were Unweighted Pair-Group Average (UPGA) and Single Linkage. For cluster analyses of the vascular plant flora the matrix was filled by weighted values of the species abundances: 1 - single or rare, scarce, 2 - scattered or moderately abundant, and 3 - common or abundant. Values like $1.5,2.5$ etc. were used in intermediate cases. The amount of dead wood on the plots was classified as follows: medium - five fallen and erect trunks of 8-20 cm in diam and a moderate number of fallen branches, $2-5 \mathrm{~cm}$ in diam; abundant - seven to nine fallen or erect trunks, $8-30 \mathrm{~cm}$ in diam (Fig. 2); very abundant -12 fallen or erect trunks, $5-35 \mathrm{~cm}$ in diam and many fallen branches, $2-5 \mathrm{~cm}$ in diam.

\section{The sample plots}

1 - Hrodna voblasts' (region), Smarhon' district, $2.8 \mathrm{~km}$ $\mathrm{N}$ of Kreva settlement, $1.5 \mathrm{~km}$ E of Tamasouka steading, $54^{\circ} 20^{\prime} 10^{\prime \prime} \mathrm{N}, 26^{\circ} 17^{\prime} \mathrm{E}$; alt. $280 \mathrm{~m}$; spruce-aspen forest of Oxalis type, with several oaks and scattered Corylus avellana; common shrubs, dwarf shrubs and herbs were
Rubus idaeus, Vaccinium myrtillus, Galeobdolon luteum, Stellaria holostea, Oxalis acetosella. Betula pendula and Pinus sylvestris were here found only as dead wood. According to Yurkevich (1980) this coenosis can be classified as Tremuletum oxalidosum, and it is a secondary community derivative from broadleaf-spruce forest, which has characteristic nemoral herb cover and old oak trees growing near the study plot. The amount of dead wood is medium.

2 - Minsk voblasts' and district, $1.5 \mathrm{~km}$ WNW of Khadakova village, Prylukski Forest Sanctuary, $53^{\circ} 47^{\prime} \mathrm{N}$, $27^{\circ} 22^{\prime} 20^{\prime \prime} \mathrm{E}$; alt. $240 \mathrm{~m}$; spruce-oak forest of Oxalis-Aegopodium type, with admixture of Populus tremula, Acer platanoides and Betula pendula. The coenosis is Quercetum aegopodiosum and this site is slightly dominated by oak, but surrounded by spruce-dominated area (Fig. 2). The amount of dead wood is abundant.

3 - Minsk voblasts', Lahoisk district, $0.8 \mathrm{~km}$ ENE of Litsvinkava village, $54^{\circ} 8^{\prime} \mathrm{N}, 27^{\circ} 44^{\prime} 20^{\prime \prime} \mathrm{E}$; alt. $270 \mathrm{~m}$; aspen-spruce forest of Stellaria holostea-Oxalis type, with admixture of Quercus robur, Betula pendula and Acer platanoides. The coenosis is Piceetum oxalidosum. The amount of dead wood is very abundant.

4 - Vitsebsk voblasts', Talachyn district, $1.1 \mathrm{~km}$ SE of Mikhailoushchyna village, 542 $6^{\prime} \mathrm{N}, 2^{\circ} 49^{\prime} 40^{\prime \prime} \mathrm{E}$; alt. $210 \mathrm{~m}$; aspen-oak-spruce forest with admixture of Alnus incana and Corylus avellana in shrub level. The herb cover is dominated by Oxalis acetosella, Dryopteris $f$ lix-mas and D. carthusiana. The coenosis is a mixture of Piceetum oxalidosum and P. aegopodiosum. The amount of dead wood is abundant.

In floristic classification the plant association on plot 1 is Rubo saxatilis-Populetum tremulae Korotkov 1986, and on plots 2, 3 and 4 is Querco-Piceetum Wł. Matuszkiewicz 1952 em. Mat. \& Polak. 1955.

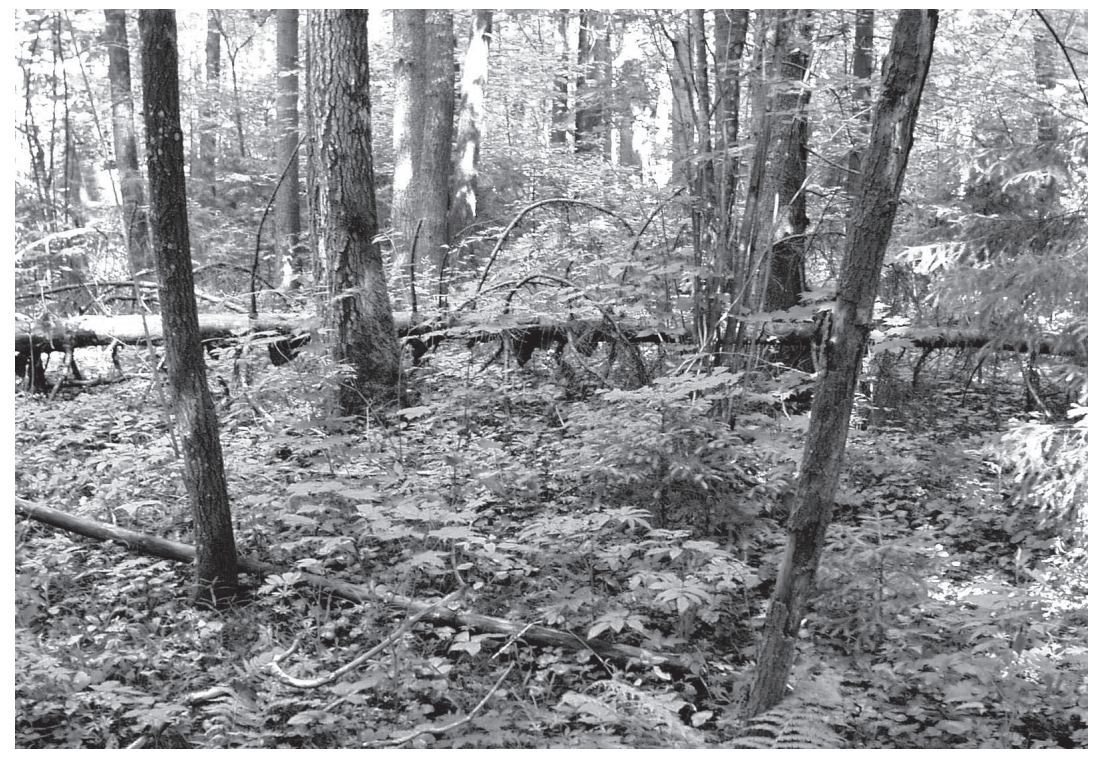

Fig. 2. A view from aspen-spruce-oak forest of Oxalis-Aegopodium type in Minsk Eminence (permanent sample plot 2), showing the amount of dead wood classified as 'abundant'. 


\section{Results}

Altogether 77 species of corticioid fungi were recorded from the sample plots (Table 1). It is 63\% of the known species from BMR Province [123 species according to Yurchenko (2003a) plus additional herbarium data]. The largest genera per plot were Hyphodontia, with five to seven species, and Peniophora, with three to four species, that constitutes $12-23 \%$ and $7.5-10 \%$ of total number of species, respectively. The genus Sistotrema encountered one to four species per plot, and several genera contained up to three species: Athelia, Phlebiella and Botryobasidium (three species on plot 1 only). Seven species, Athelia fibulata, Hyphodontiella multiseptata, Leptosporomyces fusoideus, Phlebiella tulasnelloidea, Sistotrema efibulatum, Tomentella fibrosa and Tubulicrinis sororius, were all recorded but a single locality for Belarus. Four species recorded are classified as very rare in Belarus, and these are the second known localities for Conferticium ochraceum, Hyphoderma definitum, Hypochnicium lundellii and Phlebiella allantospora.

The species composition varied in different samplings and seasons, each subsequent sampling added $8-16$, in average 13 species to list of species (Table 2).

Table 1. List of species and number of their finds or collections per plot.

\begin{tabular}{|c|c|c|c|c|}
\hline \multirow[t]{2}{*}{ Species } & Tre1/As & Que1/Mi & Pic1/Mi & Pic1/Or \\
\hline & 1 & 2 & 3 & 4 \\
\hline Amphinema byssoides & & & 5 & \\
\hline Athelia arachnoidea (in state of mycelium and sclerotia) & & 1 & 3 & 1 \\
\hline $\begin{array}{l}\text { Athelia epiphylla complex, } \\
\text { Athelia cf. epiphylla complex }\end{array}$ & 2 & 2 & 12 & 5 \\
\hline Athelia fibulata & & & 3 & \\
\hline Botryobasidium laeve, $B$. cf. laeve & 4 & & & \\
\hline Botryobasidium medium in state of Haplotrichum medium & & & & 1 \\
\hline Botryobasidium subcoronatum, B. cf. subcoronatum & 10 & & & 2 \\
\hline Botryobasidium vagum & 1 & & & \\
\hline Botryohypochnus isabellinus & & & 2 & \\
\hline Brevicellicium olivascens & 5 & 2 & 3 & 2 \\
\hline Byssomerulius corium & 2 & & & \\
\hline Ceraceomyces borealis & & & 1 & \\
\hline Ceraceomyces eludens & & & & 1 \\
\hline Ceraceomyces microsporus & & & 1 & \\
\hline Ceratobasidium cornigerum & 3 & & & 5 \\
\hline Conferticium ochraceum & 1 & & & \\
\hline Cylindrobasidium evolvens & 1 & 2 & 1 & 1 \\
\hline Dendrothele alliacea & & 1 & & \\
\hline Gloeocystidiellum porosum & & 1 & 1 & \\
\hline Hymenochaete tabacina & & 1 & & 2 \\
\hline Hyphoderma definitum & & & 1 & \\
\hline Hyphoderma praetermissum complex & & 1 & 4 & 1 \\
\hline Hyphoderma setigerum & & 3 & 3 & 5 \\
\hline Hyphodontia barba-jovis & & & & 1 \\
\hline Hyphodontia breviseta & 1 & & & 1 \\
\hline Hyphodontia crustosa & & 4 & 1 & \\
\hline Hyphodontia nespori & & 3 & 1 & 1 \\
\hline Hyphodontia pallidula & & & & 2 \\
\hline Hyphodontia paradoxa & 1 & 2 & & 1 \\
\hline Hyphodontia radula & & 1 & 3 & \\
\hline $\begin{array}{l}\text { Hyphodontia rimosissima, } \\
\text { H. cf. rimosissima }\end{array}$ & 2 & 8 & 3 & \\
\hline $\begin{array}{l}\text { Hyphodontia sambuci, } \\
\text { H. aff. sambuci }\end{array}$ & 1 & 2 & 2 & 5 \\
\hline
\end{tabular}




\begin{tabular}{|c|c|c|c|c|}
\hline Hyphodontia subalutacea & 1 & 5 & & \\
\hline Hyphodontiella multiseptata & & & & 2 \\
\hline Hypochnicium lundellii & & & & 1 \\
\hline Irpex lacteus & & & 1 & \\
\hline Lagarobasidium detriticum & & & & 1 \\
\hline Leptosporomyces fusoideus & 1 & & & \\
\hline Leptosporomyces galzinii & & & & 2 \\
\hline Peniophora cinerea & 1 & 1 & 6 & 1 \\
\hline Peniophora incarnata complex & 3 & 1 & 3 & 1 \\
\hline Peniophora nuda & & & 1 & \\
\hline Peniophora polygonia & 1 & & & \\
\hline Peniophora quercina & & 2 & 2 & 2 \\
\hline Phanerochaete laevis & 1 & 1 & & \\
\hline Phanerochaete sordida & 4 & & 1 & \\
\hline Phanerochaete velutina & & & & 6 \\
\hline Phlebia aurea & 1 & & 1 & \\
\hline Phlebia rufa & & & & 1 \\
\hline Phlebia tremellosa & & & & 1 \\
\hline Phlebiella allantospora & & 1 & & \\
\hline Phlebiella cf. pseudotsugae & & & 1 & \\
\hline Phlebiella sulphurea & & & 2 & \\
\hline Phlebiella tulasnelloidea & & & 1 & \\
\hline Radulomyces confluens & & & & 5 \\
\hline Radulomyces molaris & & 1 & & \\
\hline Resinicium bicolor & 2 & & & 1 \\
\hline $\begin{array}{l}\text { Sistotrema brinkmannii, } \\
\text { S. cf. brinkmannii }\end{array}$ & 3 & 3 & 4 & 1 \\
\hline Sistotrema efibulatum & & & 1 & \\
\hline Sistotrema oblongisporum & & & 3 & \\
\hline Sistotrema octosporum & & 1 & 1 & 1 \\
\hline Sistotremastrum niveocremeum & & 1 & 3 & 3 \\
\hline Steccherinum fimbriatum & & 4 & 8 & 3 \\
\hline Steccherinum ochraceum & & 1 & & \\
\hline Stereum hirsutum & 2 & 1 & 1 & 2 \\
\hline Stereum rugosum & & & 2 & 1 \\
\hline $\begin{array}{l}\text { Tomentella atramentaria, } \\
\text { T. cf. atramentaria }\end{array}$ & & & 3 & \\
\hline Tomentella coerulea & 1 & & & \\
\hline Tomentella fibrosa & & & 1 & \\
\hline Tomentella sublilacina & 4 & & & \\
\hline Trechispora farinacea & & & 1 & \\
\hline Trechispora microspora & 2 & 1 & 3 & 3 \\
\hline Tubulicrinis sororius & 1 & & & \\
\hline Tubulicrinis subulatus & 2 & & & \\
\hline Uthatobasidium fusisporum & & & & 1 \\
\hline $\begin{array}{l}\text { Vuilleminia comedens, } \\
\text { V. cf. comedens (immature or destroyed basidiomata) }\end{array}$ & & 2 & 6 & 1 \\
\hline Unidentified sp. MSK 5909 & 1 & & & \\
\hline
\end{tabular}

Remarks: ${ }^{1}$ Athelia epiphylla s. str. and A. ovata were distinguished, but several specimens could not be classified in any "species" within the complex. ${ }^{2}$ Clamps scattered both on basal and subhymenial hyphae. 
Table 2. Sampling dates and number of recorded species (in brackets; samplings 2 and 3 show the ratio species collected / new for the plot).

\begin{tabular}{|l|l|l|l|l|}
\hline \multirow{2}{*}{$\begin{array}{l}\text { Sampling } \\
\text { No. }\end{array}$} & \multicolumn{4}{|l|}{ Study plot No. and the abbreviations accepted in reference specimens labels } \\
\cline { 2 - 5 } & $\mathbf{1}(\mathrm{Tre} 1 / \mathrm{As})$ & $\mathbf{2}(\mathrm{Que} 1 / \mathrm{Mi})$ & $\mathbf{3}(\mathrm{Pic} 1 / \mathrm{Mi})$ & $\mathbf{4}(\mathrm{Pic} 1 / \mathrm{Or})$ \\
\hline 1 & 27 and 28 V 2001 (22) & 24 IV 2001 (17) & 30 IV 2001 (25) & 22 IV 2001 (9) \\
\hline 2 & 5 VII 2003 (19/8) & 29 VI 2003 (20/13) & 9 XI 2003 (31/16) & 19 IX 2001 (19/15) \\
\hline 3 & & & & 27 VI 2003 (21/14) \\
\hline
\end{tabular}

The number of species unique for each plot and the number of species recorded in a single locality for Belarus were in general proportional to the number of species in the community (Table 3 ).

Table 3. Species diversity in sample communities.

\begin{tabular}{|l|l|l|l|l|}
\hline Plot No. & $\mathbf{1}$ & $\mathbf{2}$ & $\mathbf{3}$ & $\mathbf{4}$ \\
\hline (1) Total number of species recorded & 30 & 30 & 41 & 38 \\
\hline (2) The number of species unique for the plot & 11 & 4 & 16 & 13 \\
\hline (3) The number of species new for Belarus & 2 & 0 & 4 & 1 \\
\hline
\end{tabular}

Since no sampling in autumn was carried out on plots 1 and 2, the effect of season on species diversity can be more significant there than the amount of dead wood.

The genera recorded on all four plots were Athelia, Brevicellicium, Cylindrobasidium, $\mathrm{Hy}$ phodontia, Peniophora, Phanerochaete, Sistotrema, Stereum and Trechispora. Consequently the species observed on all plots were Athelia epiphylla complex, Brevicellicium olivascens, $C y$ lindrobasidium evolvens, Hyphodontia sambuci, Peniophora cinerea, P. incarnata, Sistotrema brinkmannii, Stereum hirsutum and Trechispora microspora. None of the common species of the genus Phanerochaete was recorded from all plots. The species recorded on three of four plots were Athelia arachnoidea, Hyphoderma praetermissum complex, Hyphoderma setigerum, Hyphodontia nespori, $H$. paradoxa, H. rimosissima, Peniophora quercina, Sistotrema octosporum, Sistotremastrum niveocremeum, Steccherinum fimbriatum and Vuilleminia comedens. Species recorded from all four or three plots can be consider as characteristic species of broadleaf-spruce forests. Among them $S$. fimbriatum occurs as an active cord-forming colonizer with a wide host spectrum in plant debris and forest litter.
At the same time the assemblages of species having the highest frequency or abundance value were quite different on each plot. The list of common or rather common species on plot 1 consisted of Botryobasidium laeve, B. subcoronatum, Brevicellicium olivascens, Phanerochaete sordida, Sistotrema brinkmannii and Tomentella sublilacina. All these species were collected both in 2001 and 2003, except B. subcoronatum, which was collected in 2003 only. Rather frequent Ceratobasium cornigerum was collected 3 times, but only in 2001 .

The most frequent species on plot 2 were $\mathrm{Hy}$ phoderma setigerum, Hyphodontia crustosa, $H$. rimosissima, H. subalutacea, Sistotrema brinkmannii and Steccherinum fimbriatum. A peculiarity of the community is the high number (7) of Hyphodontia species. Some species were recorded several times, but in one year only. For instance, Brevicellicium olivascens was found twice in 2001, Cylindrobasidium evolvens twice in 2003, Hyphodontia nespori three times in 2003, Hyphodontia paradoxa two times in 2001, Peniophora quercina two times in 2003, and Steccherinum fimbriatum 4 times in 2003, respectively.

The dominating species on plot 3 were $\mathrm{Am}$ phinema byssoides, Athelia epiphylla s. 1., 
Brevicellicium olivascens, Hyphoderma praetermissum, Hyphodontia radula, Peniophora cinerea, P. incarnata, Sistotrema brinkmannii, Sistotremastrum niveocremeum, Steccherinum fimbriatum, Tomentella atramentaria (incl. T. cf. atramentaria), Trechispora microspora and Vuilleminia comedens. The feature of this community is the prominent abundance of some species, e.g. Amphinema byssoides was observed five times, Athelia epiphylla complex - in 13 samples, Peniophora cinerea - in five samples, Steccherinum fimbriatum eight times, and Vuilleminia comedens six times.
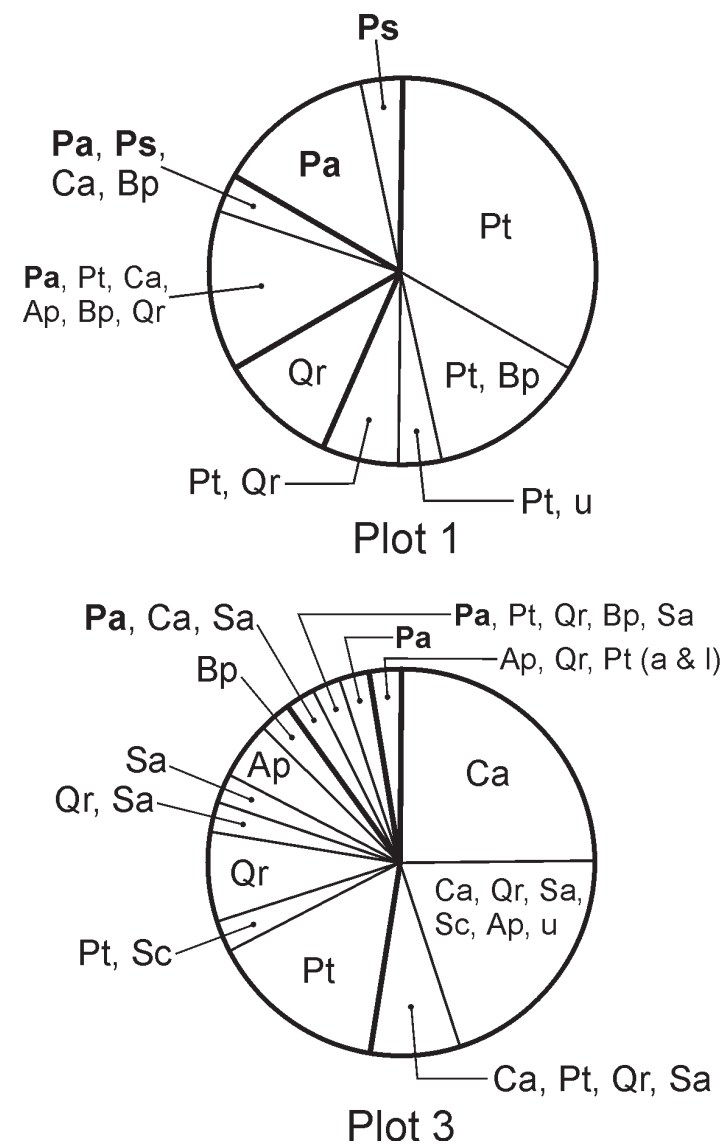

The most common species on plot 4 were Ceratobasidium cornigerum, Hyphoderma setigerum, Hyphodontia sambuci, Phanerochaete velutina (all samples in September, 2001), Radulomyces confluens, Sistotremastrum niveocremeum and Trechispora microspora.

The diagrams illustrating fungal species proportion in sample communities in respect to the host preferences are shown in Fig. 3. The species are grouped according to the hosts, e.g. ' $\mathrm{Ca}$ ' shows the percentage of the species found solely on Corylus avellana and ' $\mathrm{Ca}$, Qr, Pt' shows the percentage of the species growing on these three hosts.

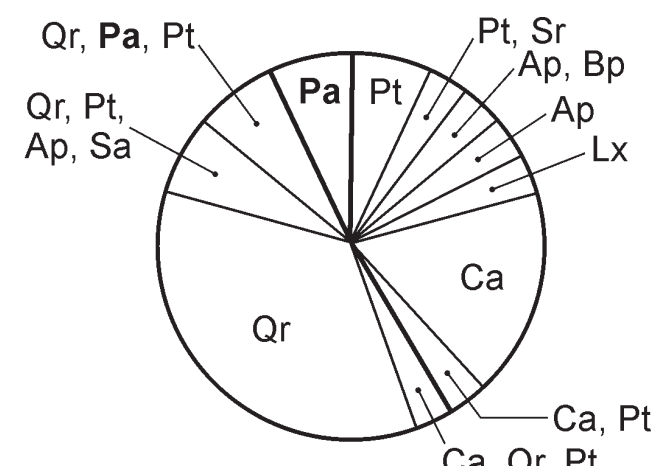

Plot 2

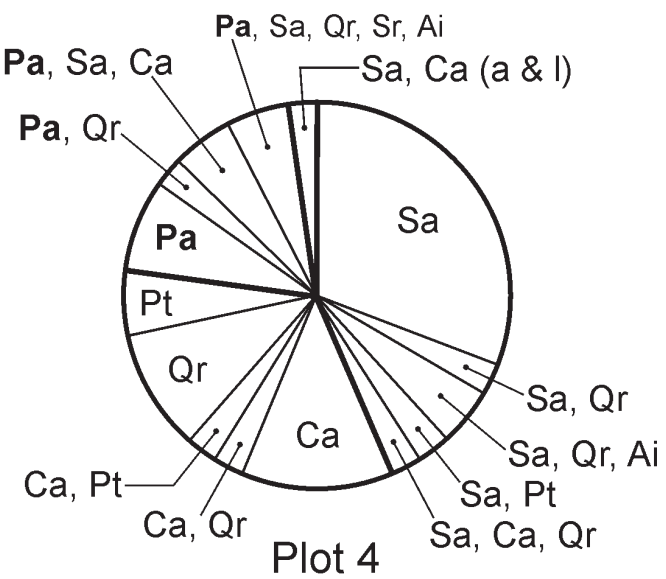

Fig. 3. Diagrams showing the proportions of species on different hosts. Abbreviations: Ai - Alnus incana, Ap - Acer platanoides, Ca - Corylus avellana, Bp - Betula pendula, $\mathbf{L x}$ - Lonicera xylosteum, Pa - Picea abies, Ps - Pinus sylvestris, $\mathbf{P t}$ - Populus tremula, $\mathbf{Q r}$ - Quercus robur, $\mathbf{S a}-$ Sorbus aucuparia, $\mathbf{S c}-$ Salix caprea, $\mathbf{S r}-$ Sambucus racemosa, $\mathbf{u}$ - unidentified host, (a \& l) - on algae and lichen thalli inhabiting indicated plants. 
On plot 1,19 species $(63 \%$ of all species on the plot) were observed on Populus tremula, eight (27\%) on fallen branches around two Quercus robur trees, and nine (30\%) were collected from Picea abies. Solely on spruce grew only Botryobasidium vagum, Conferticium ochraceum, Hyphodontia breviseta and Tubulicrinis subulatus.

On plot 2 the richest corticioid assemblage was on Quercus robur with 15 (50\%) species, and 10 species grew only on this host. Populus tremula with eight species $(27 \%)$ is followed by Corylus avellana with seven species (23\%). Only four species (13\%) were observed on Picea abies, viz. Hyphodontia nespori, $H$. subalutacea, Sistotrema octosporum and Sistotremastrum niveocremeum.

Plot 3 is characterized by a rich assemblage of species on Corylus avellana: 22, or 55\% grew on this host, and a quarter of species were found on this host only. Aspen is colonized by 11 species $(27.5 \%)$, and only four species $(10 \%)$, were recorded on Picea abies (Amphinema byssoides, Sistotrema efibulatum, S. octosporum and Steccherinum fimbriatum). For the species growing solely on one host I regard the host as the main nutritive substratum. However, in some cases the connections with the host organisms (e.g. Corylus avellana) are more complex, and fungi occupy also other substrata in contact with Corylus bark, like Phanerochaete sordida on fallen Picea abies needles, and Tomentella fibrosa, which was associated with the stipe base hairs of living Mycena galericulata (Scop.) Schaeff. and living mosses.

On plot 4 plenty of species (22, or $56.5 \%)$ colonized Sorbus aucuparia. Twelve of them (31\%) were found on this host only. Corylus avellana was colonized by 11 species (28\%), and eight species $(20.5 \%)$ were collected on Picea abies (Ceratobasidium cornigerum, Hyphodontia sambuci, Hyphodontiella multiseptata, Leptosporomyces galzinii, Phanerochaete velutina, Resinicium bicolor, Sistotrema octosporum and Steccherinum fimbriatum).

The influence of geographical distance between the sample plots is shown in Table 4 (Q.S.), with additional data of one previously studied plot in Byarezinski Reserve - Pic1/BR (Yurchenko 2003b). The average similarity between four sample communities of Querco-Piceetum $(2,3,4$, Pic1/BR) was constituted $52.4 \%$. It shows a rather high individuality of fungal species structure in forest sites with similar vegetation. The average Q.S. for all five communities studied was $46.1 \%$. The highest similarity $\mathrm{C}=62.0$ was between spatially the closest plots 2 and 3. When Pic1/BR was compared with the four plots discussed here, the coefficient was directly dependent on the geographical distance. In certain degree the community of plot 3 behaves similarly.

Table 4. Sørensen's Quotient of Similarity (\%) between corticioid fungi in five communities and distance ( $\mathrm{km}$, after '/') between the sample plots.

\begin{tabular}{|c|c|c|c|c|}
\hline & Pic1/BR & 4 & 3 & 2 \\
\hline 1 & $28.9 / 137$ & $40.6 / 226$ & $33.8 / 97$ & $43.3 / 94$ \\
\hline 2 & $42.1 / 123$ & $58.0 / 174$ & $62.0 / 45$ & \\
\hline 3 & $55.2 / 78$ & $50.0 / 141$ & & \\
\hline 4 & $47.0 / 103$ & & & \\
\hline
\end{tabular}

The results of cluster analyses which are based on the list of species (Boulean data set: 1 - presence of species, 0 - absence) are shown on Fig. 4. 

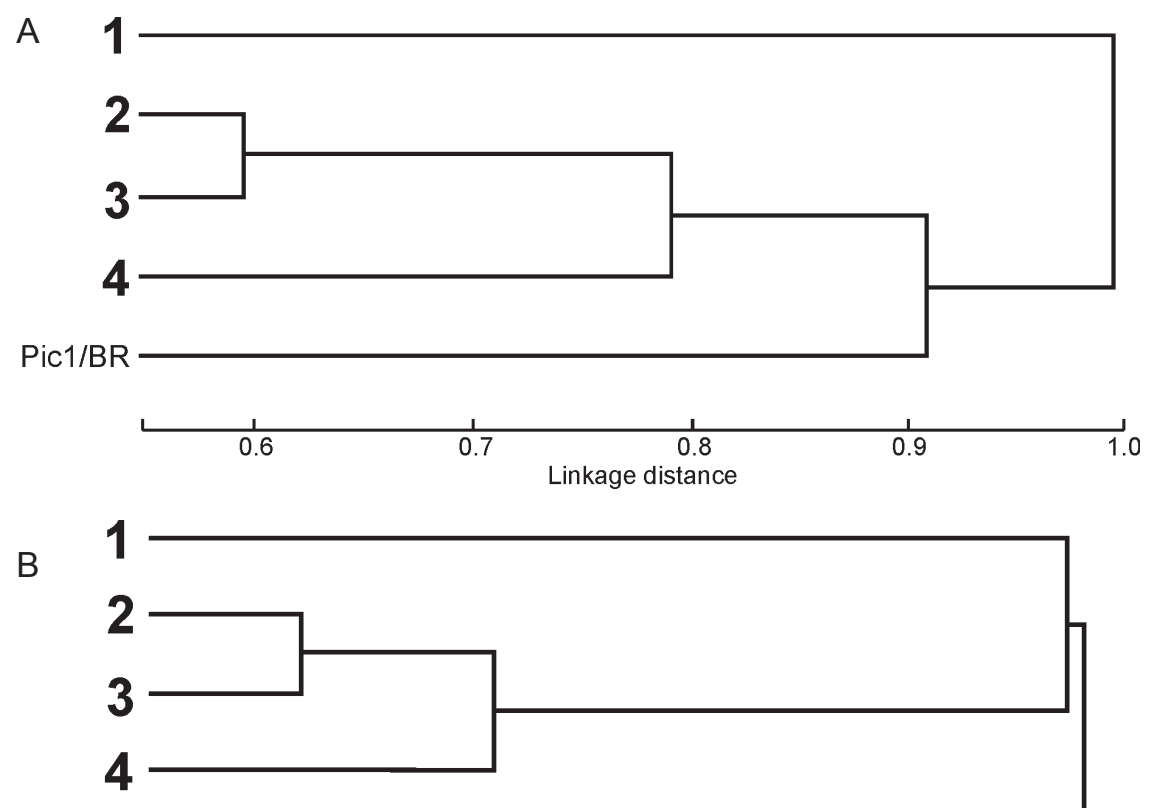

Pic1/BR

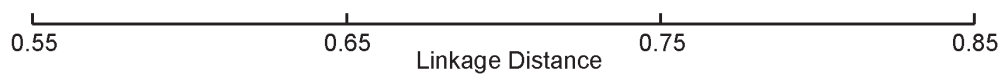

Fig. 4. Results of cluster analyses, examining similarity of corticioid species assemblages in broadleaf-spruce communities. A - dendrogram built using UPGA algorithm, B - using Single Linkage algorithm. Distance measure - 1-Pearson $\mathrm{r}$.

The dendrograms suggest that geographical distance has certain effect on the communities 2, 3, 4 and Pic1/BR, while community 1 differs due to its divergent tree composition. The geographically closest communities 2 and 3 in Minsk Eminence, respectively, join closely on both dendrograms.

A cluster analysis based on vascular plants was also made (Fig. 5). The species common for all four communities include the trees - Picea abies, Populus tremula, Quercus robur, shrubs - Corylus avellana, Sorbus aucuparia (on plot 4 also trees), Rubus idaeus and herbs - Oxalis acetosella, Aegopodium podagraria, Dryopteris carthusiana, Anemonoides nemorosa, Ajuga reptans, Viola riviniana, Majanthemum bifolium and Luzula pilosa.

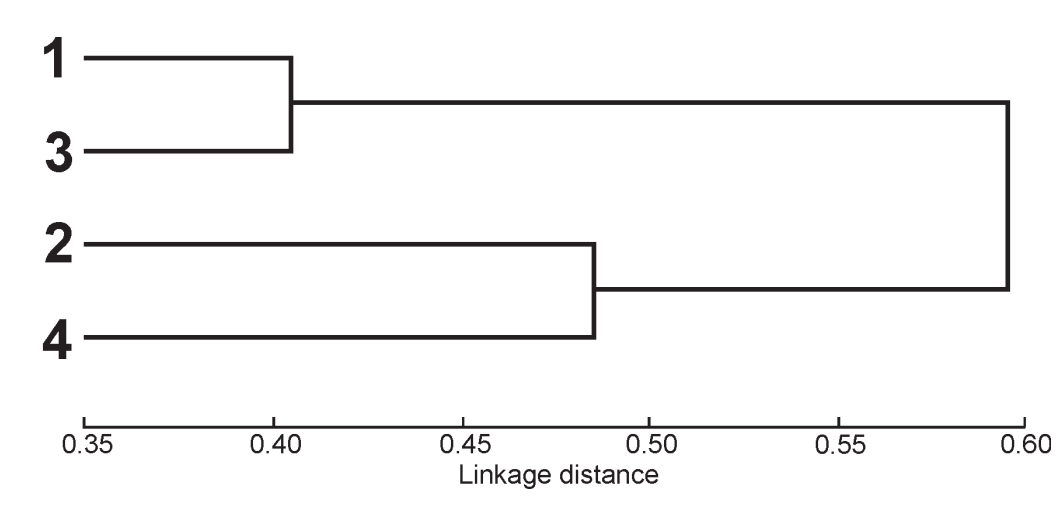

Fig. 5. Dendrogram of similarity between vascular plants assemblages built using UPGA algorithm. Distance measure -1-Pearson r. 


\section{Discussion}

Number of species. Summarizing the results of Yurchenko (2003b) and the present study I have calculated the average number of corticioid species (n) in different forest types. In Pinus sylvestris forests of Vaccinium myrtillus-Vaccinium vitis-idaea-Pleurozium schreberi type $\mathrm{n}=23$, in swamp forests with Alnus glutinosa and Betula pubescens $\mathrm{n}=26$, and in mesic broadleaf-spruce forests of Aegopodium-Oxalis type $\mathrm{n}=37$. Thus the broadleaf-spruce communities can act as some kind of diversity reservoirs for wood-inhabiting fungi. The abundance of dead wood in such communities, including coarse wood debris, rises the conservational value of such coenoses and they can be used as target objects when selecting Woodland Key Habitats (see Auziņš \& Ek 2001, Kitnæs \& Forfang 2001, Andersson et al. 2003).

Genera and species structures. The most species-rich genera in broadleaf-spruce communities (3-6 species / plot) were Athelia, Botryobasidium, Hyphodontia, Peniophora, Phlebiella and Sistotrema. This complex differs slightly from the composition in boreal coniferous forests. According to my collections in pine and pine-spruce forests in Byarezinski Reserve the genera constituting 3-5 species per $400 \mathrm{~m}^{2}$ plot were Botryobasidium, Hyphodontia, Phlebiella, Tomentella and Trechispora.

Four of the species constant in broadleafspruce forests are ubiquists and found in many other communities as well (Hyphodontia sambuci, Peniophora cinerea, Sistotrema brinkmannii and Stereum hirsutum). Several species, like Sistotremastrum niveocremeum, prefer 'forests on fertile soils' (Hjortstam \& Larsson 1997). I add to this group also Brevicellicium olivascens, Dendrothele alliacea, Hyphodontia paradoxa and $H$. radula. Some species recorded belong to typical boreal coniferous forest element, like Amphinema byssoides, Hyphodontia breviseta, $H$. pallidula, Phlebiella sulphurea and Resinicium bicolor. Moreover, Trechispora microspora is characterized by Hjortstam and Larsson (1997) as an inhabitant of conifer forests in Northern Europe, but according to my data it has quite a wide ecological range at least in Belarus. The plot 3 differs from the others due to the presence of two species, Amphinema byssoides and Phlebiella sulphurea, which are usually abundant in pine forests in Belarus.
Changes in species structure over time. Change in species structure in an area in different years and seasons is a common, but poorly studied phenomenon in corticioid fungi. In my collections each sampling always revealed species new for the study plot. However, in comparison with, e.g., the observed diversity of mycorrhizal and humus-inhabiting agarics, the assemblage of wood-inhabiting fungi is considerably more constant. Naturally, to observe the short-living or ephemeral basidiomata of many species is difficult and often accidental (Renvall 1995, Fryar et al. 1999). Remarkable changes in fungal populations are caused by succession of the forest / tree age, changes in herb and shrub composition, and hydrological regime (Perevedentseva 2000). An additional factor affecting wood-inhabiting fungi is the temporal change in the amount of dead wood belonging to different decay classes. For instance, the biota of a forest with a lot of recently windfallen or cut wood will considerably change when the wood becomes more decayed (decay classes 2 and 3). The relatively short study period (2-3 years) permits to avoid the influence of the mentioned factors.

Factors determining fungal assemblages. The number of wood-inhabiting species increases when the amount of dead wood increases (e.g., Stokland et al. 1997, Fig. 2). The number of woodinhabiting basidiomycete species rises when the amount of wood debris - especially the length of branches and consequently also the total dead wood surface - increases (Fryar et al. 1999). The richest corticioid assemblage was observed on the plot 3 with the highest amount of dead wood (Table 3), even if it was mostly of anthropogenic origin, i.e. a big decaying pile of cut branches and small trunks. This confirms that the best way to conserve corticioid fungi is to preserve dead wood as much as possible in the landscape.

The separation of the fungal complex of plot 1 (Rubo saxatilis-Populetum tremulae) from the other plots (Querco-Piceetum) is rather clear (Fig. 4 A). The remote position of Pic1/BR (Fig. $4 \mathrm{~B}$ ) is explained by the exclusive richness of tree species together with little anthropogenic disturbance, because the plot is situated inside the reserve. However, the communities with the most similar fungal assemblages ( 2 and 3 ) divide into different clusters when the similarity of vascular plants assemblages is considered (Fig. 5). Thus, the fungal assemblages are only a little depend- 
ent on the whole vascular plant flora, but more dependent on those plants which determine the type of the plant association.

The proportion of different woody plant species in biocoenoses is a factor determining the species structure of corticioid fungi. In this study the plot 1 differed from the others by the dominance of aspen tree. It is also a transitional region to adjacent aspen and pine forests. The only specimen of Tubulicrinis sororius was collected here from Pinus sylvestris. Naturally, the more substrate the host tree is producing, the more species are found from it. Most of the species recorded from plot 1 were growing on Populus tremula, on plot 2 most of the species colonized oak wood, on plot 3 Corylus avellana hosted the largest proportion of species, and on plot 4 large windfallen Sorbus aucuparia had plenty of species. Also the chemical and physical characteristics of Sorbus wood and bark evidently make it - as well as Corylus avellana - favourable for corticioid fungi, as was already stressed by Yurchenko (2003b).

Regardless of the considerable amount of $\mathrm{Pi}$ cea abies in all four communities, it was inhabited by a few species only and lacked characteristic ones.

Data on Athelia arachnoidea and Sistotrema octosporum. Some species were interesting in respect to their ecogeography. Necrotrophic Athelia arachnoidea, better known as a synanthropic species (Yurchenko \& Golubkov 2003), was observed attacking living epiphytic coccoid algae and lichens in communities 2, 3 and 4 . It seems to be rather common in mixed spruce forests on rich soils. All the records of Sistotrema octosporum on plots 2, 3 and 4 are from Picea abies. It was found on bark of dead erect trunk (MSK 6315), on bark of fallen middle-sized branch (MSK 6201) and also inside a stump (MSK 5825). According to Eriksson et al. (1984: 1349-1351) S. octosporum occurs frequently in moss cover in humid microhabitats on smallsized plant remnants. Later Hjortstam and Larsson (1997) wrote that $S$. octosporum commonly grows on a wide variety of hosts. The species was earlier known in Belarus from a single locality in Byarezinski Biosphere Reserve only, on dead stem bases of Chamaenerion angustifolium in an abandoned garden (Yurchenko 2000). According to this study it seems to be rather common in central part of Belarus.
Acknowledgements: I am grateful to Dr H. Kotiranta (Finnish Environment Institute, Helsinki, Finland) for reviewing the MS. My sincere thanks are to Dr I. Melo (MNHN: Museu e Jardim Botanico, Universidade de Lisboa, Portugal) for the help in identification of Tomentella atramentaria, T. coerulea and T. sublilacina, to Dr H. Kotiranta for revision and identification of some collections, and to Hbl.Dr I.M. Stepanovich (V.F. Kuprevich Institute of Experimental Botany) for the identification of plant associations according to floristic principle. The identification of Mycena galericulata (associated with Tomentella fibrosa) was kindly carried out by Dr O.V. Morozova (V.L. Komarov Botanical Institute RAS, St. Petersburg, Russia). Some of my species were compared with the specimens of KRAM-F herbarium and I owe my gratitude for assistance to Dr M. Piątek (W. Szafer Institute of Botany, Kraków, Poland).

\section{References}

Adzyarykha, U.S., Bernyakovich, I.V., Holad, Dz.S. et al. 2002: Raslinnasts'. Karta 4. Lyasy. - In: Myasnikovich, M.U., Shymau, U.M. et al. (eds), Natsiyanal'ny atlas Belarusi: 116. Belkartahrafiya, Minsk.

Andersson, L., Martverk, R., Külvik, M., Palo, A. \& Varblane, A. 2003: Woodland key habitat inventory in Estonia 1999-2002. Regio Publishing, Tartu. 112 pp. +80 pp. maps.

Auziņš, R., Ek, T. 2001: Woodland key habitats in Latvia. - In: Andersson L. et al. (eds.), Tools for preserving biodiversity in nemoral and boreonemoral biomes of Europe. Textbook 1. [Education and culture. Leonardo da Vinci]: 44-47. Naconex programme.

Dzyaments'eu, V.A. 1975: Fizika-heahrafichnae rayanavanne. - In: Belaruskaya savetskaya entsyklapedyya. T. 12: 51-52. Vydavetstva BelSE, Minsk.

Eriksson, J., Hjortstam, K. \& Ryvarden, L. 1984: The Corticiaceae of North Europe. Vol. 7: Schizopora - Suillosporium: 1279-1449. - Fungiflora, Oslo.

Fryar, S.C., Kirby, G.C. \& Hyde K.D. 1999: Species abundance patterns of two wood decay basidiomycete communities. - Fungal Diversity 3: 39-56.

Hallenberg, N., Larsson, K.-H. \& Larsson, E. 1994: On the Hyphoderma praetermissum complex. - Mycol. Res. 98(9): 1012-1018.

Hansen, L. \& Knudsen, H. (eds) 1997: Nordic macromycetes. Vol. 3: Heterobasidioid, aphyllophoroid and gastromycetoid Basidiomycetes. - Nordsvamp, Copenhagen. 444 pp.

Hjortstam, K. \& Larsson, K.-H. 1997: Corticioid fungi growing on ferns in northern Europe. - Windahlia 22: 49-55.

Kitnæs, K. \& Forfang, A.-S. 2001: Two woodland habitat mapping methods and their applications. - In: Read, H. et al. (eds), Tools for preserving woodland biodiversity. Textbook 2. [Education and culture. Leonardo da Vinci]: 61-66. Naconex program.

Lohinau, U.F. \& Hol'berh, M.A. (eds) 2002: Klimatychnyya umovy. - In: Myasnikovich, M.U., Shymau, U.M. et al. (eds), Natsiyanal'ny atlas Belarusi: 71-82. Belkartahrafiya, Minsk.

Parmasto, E. 1997: CORTBASE - a nomenclatural taxabase of corticioid fungi (Hymenomycetes). - Myco- 
taxon 61: 467-471. (http://www2.botany.gu.se/database/cortbase/cortbase.html)

Perevedentseva, L.G. 2000: Some aspects in the monitoring of agaricoid basidiomycetes in the forest coenoses of the Central Kama region. - In: Storozhenko, V.G., Krutov, V.I., Selochnik, N.N. (eds), Fungal communities in forest ecosystems. Materials of coordination investigations: 156-180. - Karelian Research Centre of RAS, Moscow, Petrozavodsk.

Renvall, P. 1995: Community structure and dynamics of wood-rotting Basidiomycetes on decomposing conifer trunks in northern Finland. - Karstenia 35: 1-51.

Stokland, J.N., Larsson, K.-H. \& Kauserud, H. 1997: The occurrence of rare and red-listed fungi on decaying wood in selected forest stands in Norway. - Windahlia 22: 85-93.

Yurchenko, E.O. 2000: Consortive bonds of corticioid fungi (Basidiomycetes) with vascular plants (Plantae vasculares) of Berezina Biospheric Reserve. - Proceedings of the National Academy of Sciences of Belarus. Series of Biological Sciences 1: 22-24.
Yurchenko, E.O. 2003a. Annotated list of non-poroid Aphyllophorales of Belarus. - Mycotaxon 86: 37-66.

Yurchenko, E. 2003b. Corticioid fungi (Basidiomycetes) in different biocoenoses of Byarezinski Biosphere Reserve, Belarus. - Karstenia 43: 55-65.

Yurchenko, E.O. \& Golubkov, V.V. 2003: The morphology, biology, and geography of a necrotrophic basidiomycete Athelia arachnoidea in Belarus. - Mycological Progress 2: 275-284.

Yurkevich, I.D. 1980: Vydelenie tipov lesa pri lesoustroitel'nykh rabotakh: Vspomogatel'nye tablitsy. 3rd ed. - Izdatel'stvo Nauka i tekhnika, Minsk. $120 \mathrm{pp}$.

Zmitrovich, I.V., Malysheva, E.F. \& Malysheva, V.F. 2003: Certain terms and notions in mycogeography: a critical survey. - In: Arefyev, S.P. et al. (eds), Bulletin of Ecology, Forest Management, and Landscape Management 4: 173-188. Publ. House of the Inst. of Northern Development, RAS, Siberian Division, Tyumen. 